\title{
Blood coagulation factors at phospholipid surfaces
}

Citation for published version (APA):

Hemker, H. C., Lindhout, M. J., \& Vermeer, C. (1977). Blood coagulation factors at phospholipid surfaces. Annals of the New York Academy of Sciences, 283(1), 104-113. https://doi.org/10.1111/j.17496632.1977.tb41758.x

Document status and date:

Published: 01/01/1977

DOI:

10.1111/j.1749-6632.1977.tb41758.x

Document Version:

Publisher's PDF, also known as Version of record

\section{Please check the document version of this publication:}

- A submitted manuscript is the version of the article upon submission and before peer-review. There can be important differences between the submitted version and the official published version of record.

People interested in the research are advised to contact the author for the final version of the publication, or visit the DOI to the publisher's website.

- The final author version and the galley proof are versions of the publication after peer review.

- The final published version features the final layout of the paper including the volume, issue and page numbers.

Link to publication

\footnotetext{
General rights rights.

- You may freely distribute the URL identifying the publication in the public portal. please follow below link for the End User Agreement:

www.umlib.nl/taverne-license

Take down policy

If you believe that this document breaches copyright please contact us at:

repository@maastrichtuniversity.nl

providing details and we will investigate your claim.
}

Copyright and moral rights for the publications made accessible in the public portal are retained by the authors and/or other copyright owners and it is a condition of accessing publications that users recognise and abide by the legal requirements associated with these

- Users may download and print one copy of any publication from the public portal for the purpose of private study or research.

- You may not further distribute the material or use it for any profit-making activity or commercial gain

If the publication is distributed under the terms of Article $25 \mathrm{fa}$ of the Dutch Copyright Act, indicated by the "Taverne" license above, 


\section{BLOOD COAGULATION FACTORS AT PHOSPHOLIPID SURFACES}

H. C. Hemker, M. J. Lindhout, and C. Vermeer

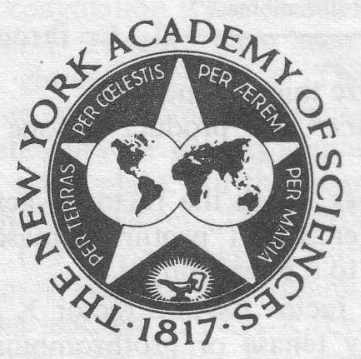

Reprinted from

ANNALS OF THE NEW YORK ACADEMY OF SCIENCES

Volume 283 Pages 104-113

February 10, 197724891 


\title{
BLOOD COAGULATION FACTORS AT PHOSPHOLIPID SURFACES
}

\author{
H. C. Hemker, M. J. Lindhout, and C. Vermeer \\ Department of Biochemistry \\ Biomedical Centre \\ State University Limburg \\ Maastricht, The Netherlands
}

The contact phase of blood coagulation results in activated factor XI.1, 2 After that the reaction sequence leading to thrombin formation is as follows:

$$
\begin{gathered}
\text { IX } \stackrel{\mathrm{XI}_{\mathrm{a}}}{\longrightarrow} \mathrm{IX}_{\mathrm{a}} \\
\mathrm{IX}_{\mathrm{a}}+\mathrm{VIII}+\text { ph.lip. }+\mathrm{Ca}^{++} \rightleftharpoons \text { "tenase" } \\
\mathrm{X} \stackrel{\text { tenase }}{\longrightarrow} \mathrm{X}_{\mathrm{a}} \\
\mathrm{X}_{\mathrm{a}}+\mathrm{V}+\text { ph.lip. }+\mathrm{Ca}^{++} \rightleftharpoons \text { "prothrombinase" } \\
\left.\mathrm{II} \stackrel{\text { "prothrombinase" }}{\longrightarrow} \mathrm{II}_{\mathrm{a}} \text { (= thrombin }\right) .
\end{gathered}
$$

Two features characterize this scheme:

1. The cascade sequence: the product of one reaction is (part of) the enzyme in the next. ${ }^{3,4}$

2. The complex enzymes. Both the factor X-activating enzyme ("tenase") and the thrombin-forming enzyme ("prothrombinase") consist of two proteins (clotting factors) adsorbed to a phospholipid.

The activated forms of factor IX and factor $\mathrm{X}$ are serine proteases. ${ }^{5-8}$ As such, they have hardly any tenase or prothrombinase activity. ${ }^{9-13}$ To obtain this activity two other components are necessary: another protein (factor VIII or factor $\mathrm{V}$, respectively) and a phospholipid, or rather, a micelle composed of a mixture of phospholipids.

The prevailing model of prothrombinase is the following: at the surface of a phospholipid micelle, factor $\mathrm{X}_{\mathrm{a}}$ and factor $\mathrm{V}$ adsorb next to each other. At the same interphase the substrate, prothrombin, adsorbs. The active site in factor $\mathrm{X}_{\mathrm{a}}$ attacks the vulnerable sites in prothrombin and so generates thrombin.

The evidence leading to this model is the following: 1) The proteins can be shown to adsorb onto the micelles. Activity generates when both adsorb onto the same micelle. $\mathrm{Ca}^{++}$is necessary for the adsorption of factor $\mathrm{X}_{\mathrm{a}}$ but counteracts the adsorption of factor V. Optimal activity is found when about equimolar quantities of both factor adsorb. ${ }^{10,11,14-20}$ The dependence of the activity on the concentrations of the constituent moieties is in accordance with the following reaction scheme: ${ }^{21,}{ }^{22}$

$$
\begin{aligned}
\mathrm{X}_{\mathrm{a}}+\mathrm{Ca}^{++}+\text {ph.lip } & \rightleftharpoons \mathrm{X}_{\mathrm{a}}-\mathrm{Ca}-\text { ph.lip. } \\
\mathrm{V}+\text { ph.lip. } & \rightleftharpoons \mathrm{V}-\text { ph.lip. } \\
\mathrm{V}+\mathrm{X}_{\mathrm{a}}-\mathrm{Ca}-\text { ph.lip. } & \rightleftharpoons \text { prothrombinase } \\
\mathrm{X}_{\mathrm{a}}+\mathrm{Ca}^{++}+\mathrm{V}-\text { ph.lip. } & \rightleftharpoons \text { prothrombinase }
\end{aligned}
$$


For tenase, an analogous set of experiments has been carried out. Adsorption and $\mathrm{Ca}^{++}$dependence ${ }^{20,23-25}$ adsorption on the same micelle ${ }^{26}$ and the kinetics of the generation of activity ${ }^{27}$ indicate a comparable reaction scheme:

$$
\begin{aligned}
\mathrm{IX}_{\mathrm{a}}+\mathrm{Ca}^{++}+\text {ph.lip. } & \rightleftharpoons \mathrm{IX}_{\mathrm{a}}-\mathrm{Ca}-\mathrm{ph} . \text { lip. } \\
\mathrm{VIII}+\text { ph.lip. } & \rightleftharpoons \mathrm{VIII}-\mathrm{ph} . \text { lip. } \\
\mathrm{VIII}+\mathrm{IX}_{\mathrm{a}}-\mathrm{Ca}-\text { ph.lip. } & \rightleftharpoons \text { tenase } \\
\mathrm{IX}_{\mathrm{a}}+\mathrm{Ca}^{++}+\mathrm{VIII}-\text { ph.lip. } & \rightleftharpoons \text { tenase }
\end{aligned}
$$

We can elaborate upon this model on the basis of the existing evidence obtained on its various components.

\section{The Active Site-Bearing Proteins (Factor $\mathrm{X}_{\mathrm{a}}$ and Factor IX F $_{\mathrm{a}}$ )}

Both active site-bearing proteins are two-chain serine proteases. ${ }^{5-8}$ The heavy chain shows extensive homologies to other members of the chymotrypsin family and contains the active serine.

The light chain is particularly interesting in that it contains several pairs of $\gamma-\mathrm{COOH}$ glutamyl residues. The dicarboxyl side chains generated bind $\mathrm{Ca}^{++28,29}$ and via $\mathrm{Ca}^{++}$bind to the phospholipid surface. ${ }^{30}$ The study of the function of these groups in coagulation is facilitated by the fact that both factor IX and factor X (and factor II as well) have been demonstrated to exist in a form without carboxylated glutamic acids. ${ }^{31,32}$ The carboxylation of the glutamic acids is brought about by a vitamin $\mathrm{K}$-dependent enzyme system. Consequently, in vitamin $\mathrm{K}$ deficiency or during administration of vitamin $\mathrm{K}$ antagonists, no carboxylation takes place. In that case, the uncarboxylated form of the protein comes into the circulation. These proteins induced by vitamin $\mathrm{K}$ absence (c.q. Antagonists) (PIVKAs) have no normal procoagulant function. Indeed, we discovered them ${ }^{33}$ because they inhibit coagulation under certain circumstances. Recently, we isolated PIVKA-X, i.e. the uncarboxylated factor $\mathrm{X}$ from anticoagulated cows. ${ }^{34}$ Like factor $\mathrm{X}$, it can be activated by a protease from Russell's viper venom. Toward small synthetic substrates it shows esterolytic and peptidolytic activity similar to that of factor $X_{a}$. Like factor $X_{a}$ it splits prothrombin in free solution. Unlike factor $\mathrm{X}$, this activity cannot be enhanced by the addition of $\mathrm{Ca}^{++}$, factor $\mathrm{V}$, and phospholipid. ${ }^{34}$ It thus seems that its active site, as well as its vulnerable site, is intact, but that due to an inability to bind to phospholipid it cannot partake in the normally active prothrombinase. Indeed, the only difference between the PIVKAs and the normal factors lies in the $\gamma$-carboxylation as has been demonstrated by Stenflo. ${ }^{28,29} \mathrm{He}$ found $\gamma$-COOH groups as the only chemical difference between PIVKA-II and prothrombin. It is further emphasized by our recent finding that PIVKA-II can be converted into prothrombin in a vitamin $\mathrm{K}$-dependent oxidative carboxylation by an enzyme system isolated from liver microsomes (TABLE 1).

\section{The Paraenzymes (FActors V and VIII)}

The function of the factors V and VIII is much less clear than those of the active site-bearing factors. Both factor V and factor VIII lack any known enzymatic property of their own. ${ }^{35-38}$ Both occur in plasma as polymers; both are rendered more active by thrombin. Thrombin has been shown to favor the 
conversion of native factor $\mathrm{V}$ in more active moieties of $1 / 4$ of the original molecular weight, although small molecular weight factor $\mathrm{V}$ does occur without the action of thrombin, and then is also active. Thrombin-activated factor $\mathrm{V}$ readily inactivates in a reaction that is a dimerization or a higher order polymerization. ${ }^{40}$ This suggests the following reactions:

$$
\mathrm{V}_{\mathrm{t}} \leftrightarrows 4 \mathrm{~V}_{\mathrm{m} . \mathrm{e}} \stackrel{\text { thrombin }}{\longrightarrow} 4 \mathrm{~V}_{\mathrm{m} . \mathrm{e}} \rightleftarrows \mathrm{V}_{\mathrm{i}}
$$

$\mathrm{t}=$ tetramer $\mathrm{m}=$ monomer; $\mathrm{e}=$ enhanced activity; $\mathrm{i}=$ inactive species.

The relative activities before and after thrombin action are unknown. Some

TABLE 1

Conversion of Pivka-II into Prothrombin in a Cell-Free System*

\begin{tabular}{|c|c|c|c|}
\hline Component & $\begin{array}{l}\text { Synthesis } \\
\text { when Omitted }\end{array}$ & Replacement & $\begin{array}{l}\text { Synthesis } \\
\text { when } \\
\text { Replaced }\end{array}$ \\
\hline Microsomal protein & 4 & thromboplastin & 5 \\
\hline Supernatant & 33 & - & \\
\hline PIVKA-II & 0 & prothrombin & 0 \\
\hline Vitamin $\mathrm{K}_{1} \quad(0.3 \mathrm{mM})$ & 33 & Warfarin $(0.1 \mathrm{mM})$ & 0 \\
\hline $\mathrm{Mg} \quad(4 \mathrm{mM})$ & 0 & $\mathrm{Ca}(4 \mathrm{mM})$ & 0 \\
\hline ATP $\quad(1.5 \mathrm{mM})$ & 22 & $\mathrm{ADP}(1.5 \mathrm{mM})$ & 80 \\
\hline $\begin{array}{l}\text { Creatine Phosphate }(5 \mathrm{~m} \\
+ \text { phosphokinase }\end{array}$ & 89 & - & \\
\hline $\begin{array}{ll}\mathrm{HCO}_{3}^{-} & (13 \mathrm{mM}) \\
\mathrm{O}_{2} & \end{array}$ & 89 & $\begin{array}{l}\mathrm{CO}_{3}^{--}(13 \mathrm{mM}) \\
\mathrm{N}_{2}\end{array}$ & $\begin{array}{l}11 \\
38\end{array}$ \\
\hline
\end{tabular}

* The activities are expressed as percentages of the synthesis rate in the complete mixture, i.e., $2 \mathrm{nM} / \mathrm{hr}$. The complete system consists of: microsomal proteins, 0.2 $\mathrm{OD}_{2 s 0}$ units; microsomal supernatant, OD ${ }_{280}$ units; PIVKA-II, 0.16 units/ml; Tris$\mathrm{HCl}$, pH 8.5, $50 \mathrm{mM}$; Sucrose, $60 \mathrm{mM}$; and $\mathrm{KCl}, 30 \mathrm{mM}$. Thromboplastin (if present) $20 \% \mathrm{~V} / \mathrm{v}$ Factor II (if present), $0.008 \mathrm{Units} / \mathrm{ml}$, which causes a comparable clotting time as $0.16 \mathrm{U} / \mathrm{ml}$ of PIVKA-II. Mixtures of $0.1 \mathrm{ml}$ were incubated for $1 \mathrm{hr}$ at $37^{\circ} \mathrm{C}$, diluted fourfold and assayed for factor II activity. The increase between the factor II activity at $\mathrm{t}=0$ and $\mathrm{t}=60 \mathrm{~min}$ was a measure for the factor II synthesis. Microsomal proteins were partly purified on DEAE cellulose. PIVKA-II was partly purified on QAE Sephadex and adsorbed three times with an excess of $\mathrm{BaSO}_{4}$ to remove the last traces of factor II.

reversibility of the inactivation has been demonstrated. It has also been demonstrated that the adsorption of factor $\mathrm{V}$ onto phospholipid enhances the adsorption of factor $\mathrm{X}_{\mathrm{a}}$. An interaction between factor $\mathrm{V}$ and factor $\mathrm{X}_{\mathrm{a}}$ on the phospholipid surface is thus probable. This may also be deduced from the observation that prothrombinase and tenase develop slowly when a large phospholipid surface is offered. ${ }^{22,27}$ This may be interpreted as being due to a small chance for the two factors to interact, but persistent activity after interaction has taken place; i.e., the equilibrium in the formation of the complex must be at the side of the complex.

The biochemistry of factor VIII is even more complicated than that of factor V. As yet, no coherent picture of its mode of conversion and action can 
be given. The reader is referred to a recent review for further information. ${ }^{41}$

Both factor V and factor VIII do adsorb on hydrophobic powders. Factor $\mathrm{V}$ has been shown to retain a good deal of its activity when adsorbed, but will not elute from the powder. ${ }^{42}$ This, together with the data on the influence of $\mathrm{Ca}^{++}$-ions suggests that the binding of factor $\mathrm{V}$ to phospholipid may also be hydrophobic.

It has been demonstrated that factor $\mathrm{V}$ has a special affinity for a fragment of the prothrombin molecule. ${ }^{43}$ Since factors $\mathrm{V}$ and VIII have no enzymatic activity of their own but specifically modify the enzyme with which they come in contact, we baptized them paraenzymes.

\section{The Substrate}

The substrate of prothrombinase is prothrombin. Prothrombinase brings about two cleavages of the primary structure, one at the Arg 373-Ile 374 bond. The active site-bearing $\beta$-chain of thrombin thus comes into being. The other is the Arg 274-Thr 275 bond that splits off thrombin $\alpha$ - and $\beta$-chain from the prothrombin molecule. The remainder of the molecule (the "pro"-part) contains the $\mathrm{Ca}^{++}$and phospholipid-binding site; it can be again split by thrombin. ${ }^{44-48}$

PIVKA-II, which does not bind to phospholipid, is not a suitable substrate for prothrombinase, although it does contain normal thrombin ${ }^{49}$ and will react like normal prothrombin when activated in free solution, either by proteolysis $\left(\right.$ Ecarin ${ }^{50}$ ) or by stoichiometric complexation with staphylocoagulase and subsequent change of tertiary structure. ${ }^{51}$

Factor $\mathrm{X}$ has been reported not to bind to phospholipid, but when it is activated, it does. It is not yet known if PIVKA-X is activated by "tenase."

\section{THE PHOSPHOLIPID}

Two types of protein-lipid interaction seem to be necessary: interaction of charged groups via $\mathrm{Ca}^{++}$and hydrophobic interaction. The charge of the micelles will influence the possibilities for both $\mathrm{Ca}^{++}$ions and charged proteins to approach the micelle and to attach to its surface by electrostatic forces. Since it has been shown that hydrophobic interactions do play a role too, the micelle also has to offer the possibility of hydrophobic interactions. Any micelle will do this, but to what extent depends on fatiy acid chain length in the phospholipid as well as on the nature of the head groups. Therefore, apart from charge, hydrophobicity of the micelle will play a role in determining its coagulation activity.

The experiments on the formation of prothrombinase and tenase suggest that the lateral mobility of the adsorbed proteins will influence the activity of the enzymes. ${ }^{27}$ This mobility will change with the "phase" of the micelle phospholipids; i.e., liquid, liquid crystalline, or solid. The phase at the ambient temperature is a function of the composition of the micelle.

Thus there are at least three properties of the micelle that will determine its effectiveness in these enzyme complexes: phase, hydrophobicity, and charge. All three vary with the composition of the micelle. This may explain why, in binary mixtures of pure phospholipids, there is a definite composition with optimal activity. ${ }^{52-55}$ 


\section{The Role of the Phospholipid Surface}

One can imagine at least three possible roles for the phospholipid surface in the generation of prothrombinase and tenase: 1) an increase in local concentration; 2) a reduction of the degrees of freedom of the movements of the proteins; and 3) induction of favorable changes in tertiary structure.

Increase in Local Concentration. The concentration of any protein at an interphase will be determined by the concentration of that protein in the surrounding solution and its affinity for the interphase. Proteins with a high affinity for a certain type of interphase will concentrate at that interphase. In fact, it has been shown that the concentration of clotting factors at the thrombocyte surface is high. One in every thousand or ten thousand protein molecules that a clotting factor meets is the partner for its function in coagulation. A local enrichment in concentration therefore seems essential. Yet there is reason to doubt that local concentration is the only factor involved, because 1) factor $\mathrm{V}$ enhances the adsorption of factor $\mathrm{X}_{\mathrm{a}}$, so there exists a cooperative interaction of these proteins; and 2) phillipin will interact with lipids in such a way as to enhance the adsorption of clotting factors but diminish its procoagulant activity. ${ }^{56-57}$

Local concentration at an interphase is a concept that should be used with some caution, because the amount of reacting species per unit volume is hardly a useful figure in this context. The possibility of interaction of the molecules is determined by the amount per surface and the mobility when adsorbed (c.q. via the fluid phase). Moreover, orientation effects will modify the percentage of meetings that lead to a reaction. This automatically leads to the following:

A Reduction of the Degrees of Freedom of the Movements of the Proteins. The active site of an enzyme and the vulnerable site of its protein substrate form only a small fraction of its total surface. A small portion of the collisions in free solution will therefore be effective. When enzyme and substrate are adsorbed at an interphase by a specific portion of their molecule they are orientated, and only a fraction of their surfaces can meet. Favorable orientation can enhance the possibility that the meeting surface contains the active and vulnerable sites. This orientation effect can be even more pronounced when a third molecule, the paraenzyme, brings about an orientation of substrate and enzyme in the plane of the interphase. There has recently been a discussion about the possibility that entropy changes favoring the "best fit" position could account for the final adjustment of positions just before the collision between enzyme and substrate. This entropy change would correspond to free energy changes in vibrational degrees of freedom. It was concluded that in bulk the translational degrees of freedom represent too much energy to allow this kind of regulation. These translational energies, however, are considerably lower for molecules adsorbed to an interface. We are at present investigating the possibilities that in that case this "entropy mechanism" might function. (W. T. Hermens, unpublished results.)

Induction of Favorable Changes in Tertiary Structure. Changes in tertiary structure will accompany any adsorption of a protein. That they are favorable in our case and if so, to what extent, is difficult to assess at this moment. One does not conclude from kinetic measurements that changes occur that are not readily reversible. This mechanism is of prime interest in the generation of contact product, but its role in the generation of tenase and prothrombinase waits for further elucidation. 


\section{REFERENCES}

1. Ratnoff, O. D. 1976. This volume.

2. KaPLAN, A. P. 1976. This volume.

3. MacFarlane, R. G. 1964. Nature 202: 489-499.

4. Davie, E. \& O. D. Ratnoff. 1964. 1310-1312.

5. Fujikawa, K., M. E. Legaz, H. Kato \& E. W. Davie. 1974. Biochemistry 13: 5208-5216.

6. RadCliffe, R. D. \& P. G. Barton. 1972. J. Biol. Chem. 247: 7735-7741.

7. Fujikawa, K., M. E. Legaz \& E. W. Davie. 1972. Biochemistry 11: 4892-4898.

8. JACKSON, C. M. 1972. Biochemistry 11: 4873-4881.

9. Jackson, C. M., W. G. OWen, S. N. Gitel \& C. T. Esmon. 1974. Thrombos. Diathes. Haemorrh. (Suppl.) 57: 273-293.

10. Esnouf, M. P. \& F. Jobin. 1965. Thrombos. Diathes. Haemorrh. (Suppl.) 17: 103-110.

11. Jobin, F. \& M. P. Esnouf. 1967. Biochem. J. 102: 666-674.

12. BANGHAM, A. D. 1961. Nature 4808: $1197-1198$.

13. Chuang, T. F., R. B. Sargeant \& C. Hougie. 1972. Biochim. Biophys. Acta 273: 287-291.

14. Cole, E. R., J. L. Koppel \& J. H. Olwin. 1965. Thrombos. Diathes. Haemorrh. 14: 431-435.

15. Cole, E. R., J. L. Koppel \& J. H. Olwin. 1964. Can. J. Biochem. 42: 15951603.

16. Hanahan, D. J. \& D. Papahadjopoulos. 1965. Thrombos. Diathes. Haemorrh. (Suppl.) 17: 71-76.

17. Papahadjopoulos, D. \& D. J. Hanahan. 1964. Biochim. Biophys. Acta 90: 436-439.

18. Barton, P. G. \& D. J. Hanahan. 1969. Biochim. Biophys. Acta 187: 319-327.

19. Bull, R. K., S. Jevons \& P. G. Barton. 1972. J. Biol. Chem. 247: 2747-2754.

20. HemkeR, H. C. \& M. J. P. KahN. 1967. Nature 215: 1201-1202.

21. Deggeller, K. \& J. Vreeken. 1969. Thrombos. Diathes. Haemorrh. 22: 45-67.

22. Hemker, H. C., M. P. Esnouf, P. W. Hemker, A.C.W. Swart \& R. G. MacFARLANE. 1967. Nature 215: 246-251.

23. Barton, P. G. 1967. Nature 215: 1508-1509.

24. Hemker, H. C., M. J. P. Kahn \& P. P. Devilee. 1970. Thrombos. Diathes. Haemorrh. 24: 214-223.

25. Hougie, C., K. W. E. Denson \& R. Biggs. 1967. Thrombos. Diathes. Haemorrh. 18: 211-222.

26. Osterud, B. \& S. I. Rapaport. 1970. Biochemistry 9: 1854-1861.

27. Varadi, K. \& H. C. Hemker. 1976. Thrombosis Res. 8: 303-317.

28. Stenflo, J. 1975. In Prothrombin and Related Coagulation Factors. H. C. Hemker and J. J. Veltkamp, Eds. : 152-158. Leiden University Press. Leiden, The Netherlands.

29. Stenflo, J., P. Fernlund, W. Egan \& P. Roepstorff. 1974. Proc. Nat. Acad. Sci. USA 71: 2730-2733.

30. Esmon, C. T., J. W. Suttie \& C. M. Jackson. 1975. J. Biol. Chem. 250: 40954099.

31. Reekers, P. P. M., M. J. Lindhout, B. H. M. Kop-Klaassen \& H. C. Hemker. 1973. Bioch. Biophys. Acta 317: 559-562.

32. Hemker, H. C., M. J. Lindhout \& P. P. M. Reekers. 1974. In Thrombosis, Pathogenesis and Clinical Trials. Trans. Plenary Sessions IVth Int. Congress Thrombosis and Haemostasis: 45-52. Vienna, Austria.

33. Hemker, H. C., J. J. VeltKamp, A. Hensen \& E. A. Loeliger. 1963. Nature 200: $589-590$.

34. Lindhout, M. J. \& B. H. M. Kop-Klaassen. 1975. Thrombos. Diathes. Haemorrh. 34: 592 . 
35. Biggs, R. \& R. G. MacFarlane. 1965. Brit. J. Haematol. 11: 276-295.

36. Newcomb, T. F. \& M. Hashida. 1965. Scand. J. Clin. Lab. Invest. (Suppl. 17) 84: 61-69.

37. Prentice, C. R. \& O. D. Ratnoff. 1969. Brit. J. Haematol. 16: 291-302.

38. Stenflo, J. 1973. J. Biol. Chem. 248: 6325-6332.

39. Kahn, M. J. P. \& H. C. HemkeR. 1972. Thrombos. Diathes. Haemorrh. 27: 25-32.

40. Hemker, H. C. \& M. J. P. Kahn. 1972. Thrombos. Diathes. Haemorrh. 27: $33-42$.

41. Van MouriK, J. A., B. N. Bouma \& I. A. Mochtar. 1975. In Handbook of Hemophilia. K. M. Brinkhous \& H. C. Hemker, Eds. : 77-102. Excerpta Med. Amsterdam, The Netherlands.

42. Kahn, M. J. P. \& H. C. Hemker. 1969. Thrombos. Diathes. Haemorrh .22: 417-430.

43. EsMON, C. T. \& C. M. JACKson. 1974. J. Biol. Chem. 249: 7791-7799.

44. Heldebrant, C. M. \& K. G. Mann. 1973. J. Biol. Chem. 248: 3642-3652.

45. OWen, W. G., C.T. Esmon \& C. M. Jackson. 1974. J. Biol. Chem. 249: 594 605.

46. Mann, K. G., C. M. Heldebrant \& D. N. Fass. 1971. J. Biol. Chem. 246: 6106-6114.

47. Jesty, J. \& M. P. Esnouf. 1973. Biochem. J. 131: 791-799.

48. Magnusson, S., L. Sottrup-Jensen, T. Ellebaek-Petersen \& H. Claeys. 1975. In Prothrombin and Related Coagulation Factors. H. C. Hemker \& J. J. Veltkamp, Eds. : 25-47. Leiden Univ. Press. Leiden, The Netherlands.

49. Hemker, H. C., A. D. Muller \& E. A. Loeliger. 1970. Thrombos. Diathes. Haemorrh. 23: 633-637.

50. Kornalik, F. \& B. Blombäck. 1975. Thrombos. Res. 6: 53-63.

51. Hemker, H. C., B. M. Bas \& A. D. Muller. 1975. Biochim. Biophys. Acta 379: 180-188.

52. Papahadjopoulos, D., C. Hougie \& D. J. Hanahan. 1962. Proc. Soc. Exp. Biol. Med. 111: 412-416.

53. Marcus, A. J. 1966. Adv. Lipid Res. 4: 1-37.

54. Daemen, F. J. M., C. van Arkel, H. C. Hiart, C. van Drift \& L. L. M. van DEENEN. 1965. Thrombos. Diathes. Haemorrh. 13: 194-203.

55. Barton, P. G. 1969. In Structural and Functional Aspects of Lipoproteins in Living Systems. E. Tria and A. M. Scanu, Eds. : 463-515. Academic Press. New York, N.Y.

56. van der Plas, P. M., L. Kraan, G. van Es, J. Stibbe \& H. C. Hemker. 1974. J. Mol. Med. 3: 1-8.

57. van der Plas, P. M., G. van Es, L. Kraan \& H. C. Hemker. 1973. J. Mol. Med. 1: 191-204. 


\section{DISCUSSION}

Dr. Rosenberg: I think Dr. Hemker has pointed out the importance of cofactors in the coagulation mechanism. I might start out the discussion by asking both Dr. Ratnoff and Dr. Kaplan the following question: It seems to me that the high molecular weight kininogen-low molecular weight kininogen transition is a very critical one in allowing factor XII to activate its various substrates. We know that most of the kininogen circulates in the low molecular weight or inactive form. What do you think is responsible for running this process, and what effect does it have on the contact with blood?

DR. RATnOFF: That's a charmingly easy question to answer. I don't know, but I would like to talk a little about high molecular weight kininogen. In my paper, I cut out description of an experiment that was close to but not identical with the one that Dr. Kaplan described; and I might say that his data and ours are in agreement about most things. The experiment that I didn't show runs something like this. Plasma kallikrein, as was first shown by others, digests a synthetic amide, and the result is a beautiful yellow color. This, I assume, is the same substrate used by Dr. Kaplan. Kallikrein will do this in a pure system in which you just have kallikrein and the substrate. The presence or absence of high molecular weight kininogen doesn't particularly matter. Now, kallikrein adsorbs onto insoluble substances, and it does this better than Hageman factor does. In its adsorbed state, kallikrein is a very poor digestor of this synthetic substrate. It's as if-perhaps as Dr. Hemker suggests-some of those active groups are turned upside down and can't get out. If one first treats the kaolin, the activator of Hageman factor (but there is no Hageman factor in this system now), and treats it with Fitzgerald factor, this kaolin-treated Fitzgerald factor will no longer inactivate plasma kallikrein. Prevention of inactivation thus looks like activation. I think, to get back to the last sentence of my talk, everything that Dr. Kaplan and I have been talking about is artifactual. In real life we haven't any idea how these agents interreact, and we know that we're missing the point because patients lacking Hageman factor, the Fitzgerald factor, and Fletcher factor are asymptomatic. Whales live out their whole long life times without any Hageman factor or any Fletcher factor.

DR. KAPLAN: There is so far no evidence that one can convert the high molecular weight kininogen to the low in a simple enzymatic way. The high is a substrate of plasma kallikrein. Nobody has succeeded yet in converting high molecular weight kininogen into low by digesting it with kallikrein; so one of the questions is: Are these two proteins synthesized by the same gene? Antibody to low molecular weight kininogen gives a complete line of identity with the high, so the structure of the low is essentially contained within the high, which would make you think that it's not synthesized by two genes. Tagged high molecular weight kininogen added to plasma shows no conversion to the low molecular weight kininogen, so there is no obvious proteolytic process, at least in plasma, by which the high is converted to the low. Finally, I would like to put forth the following notion: we know that to make an IgG molecule you have to have a minimum of four genes - two for the light chain and two for the heavy chain. The light chain is about 22,500 molecular weight. There is a gene for the antibody-binding region and a gene for the constant region, and somehow these are put together at the transcription level or the translation 
level. I would wonder whether, in fact, there is not one gene for low molecular weight kininogen and another gene for the part of the high that differs, and that the two are put together to form the high molecular weight kininogen; but there would be an excess on the part of the one that makes low, and that's what we see in the plasma. It is interesting to note that some of the patients with high molecular weight kininogen deficiency, like our patients, have no kininogen at all, zero high and zero low. But in the Fitzgerald patient, I believe total kininogen is almost $50 \%$, yet all of it is the low form. So maybe he has that part of it but is completely missing the other half.

DR. VRoman: How can we explain that the phospholipid micelles even when suspended in a lot of plasma protein to begin with, still seem to adsorb selectively only a couple of protein species during clotting? Do you presume that there is displacement of other proteins when you start adding calcium, for example, in your system? How can trace proteins such as factors VIII and IX compete with abundant proteins such as albumin and globulins?

Dr. HemKer: I think they would compete because of their equilibrium constants between their concentration in a free solution and the concentration adsorbed. I think there is a clear indication that at least the factors II, VII, IX, and X are provided with a specific binding group to bind to these phospholipids.

Dr. B. Alexander (New York Blood Center, New York, N.Y.): Dr. Hemker, there has been no allusion to the action of naturally occurring detergent agents such as bile salts. Would you care to speculate as to their possible role regarding the lipid micelles and their possible role in activation of some of the clotting factors.

Dr. HEMKer: I have actually avoided discussing all types of physical and physicochemical circumstances that do alter the phospholipid surface, because things really get complicated.

DR. Nossel: There has been some suggestion that platelets may activate the Hageman factor system, and I wonder if Dr. Kaplan or Dr. Ratnoff has any sentiments about that phenomenon.

DR. RATNOFF: I suppose I have sentiments about everything. But as far as I know, the experiments by Dr. Walsh to which you refer have not been confirmed anywhere. And, as far as I know, there is no firm evidence that platelets will activate Hageman factor or PTA, in the presence or absence of ADP.

DR. NosSEL: Does anybody want to contradict that?

DR. RATNOFF: Just remember I said "as far as I know." I didn't say it wasn't true.

DR. WeIss: We have tried to either confirm or not confirm Peter Walsh's studies, and we've had both some success on one hand and no success on the other. The contact system is activated by kaolin more readily in the presence of platelets than in the absence of platelets. However, we could not do the same with collagen.

Dr. Ratnoff: Could we talk a little bit about terminology? High molecular weight kininogen, to the extent that we know at this point, is identical with the term "Fitzgerald factor," defined as being an agent missing in Fitzgerald trait. There are four other families that have been described in which high molecular weight kininogen is deficient. Three of these four families at least have a defect qualitatively different from Fitzgerald trait. The patients with William's trait lack not only high molecular weight kininogen-that is, Fitz- 
gerald factor-but additionally, low molecular weight kininogen, as Dr. Kaplan said. The same is true of a family of a patient named Flaujeac, lacking both high and low molecular weight kininogen, and this has been referred to as "Flaujeac trait." The same is also true of the patients named Washington in Cincinnati described as having Fitzgerald trait, but in fact deficient both in the high molecular weight kininogen-that is, the Fitzgerald factor-and in low molecular weight kininogen. Hopefully, my colleagues and I will drop this rather charming nomenclature and stick to high and low molecular weight and combined kininogen deficiencies. 